\title{
Updateable and customizable educational materials
}

Chandrasekhar Roychoudhuri, Arthur Guenther, Leno Pedrotti, Darrell Hull

Chandrasekhar Roychoudhuri, Arthur H. Guenther, Leno S. Pedrotti, Darrell M. Hull, "Updateable and customizable educational materials," Proc. SPIE 4588, Seventh International Conference on Education and Training in Optics and Photonics, (28 May 2002); doi: 10.1117/12.468685

SPIE Event: Education and Training in Optics and Photonics 2001, 2001, Singapore, Singapore 
Invited Paper

\title{
UPDATEABLE AND CUSTOMIZABLE EDUCATIONAL MATERIALS
}

\author{
Chandrasekhar Roychoudhuri (Chandra@phys.uconn.edu), \\ University of Connecticut \\ Art Guenther, University of New Mexico \\ Leno Pedrotti and Darrell Hull, CORD.
}

\begin{abstract}
:
\end{abstract}
Since the advent of the communication revolution and global Internet system, the rate of creation of new knowledge is increasing at almost a geometric rate in diversity of applied fields. The global competitive economic system is driving everybody to rush into the technology innovation process. This is acutely apparent in all technology fields, and especially, in optics/photonics. Today's technology knowledge will become almost obsolete tomorrow. Then how do we create lasting textbooks for technicians? Different industry segments use same photonic sciences but for different applications and with different emphasis on different principles. Then how do you create textbooks that are customizable for different industry sectors? Rapid innovation and competition is also creating pressure on technicians to know and learn more with appropriate mathematical foundations that high schools are unable to provide. We will present concepts and ideas on how industries, professional societies and interested individuals can create a "lasting" series of textbooks that are rapidly updateable along with extra, mathematically oriented examples to keep up with the technology changes and quickly customizable for different industry sectors. These concepts evolved through the experience of the NSF supported project, STEP (Science and technology Education in Photonics). The objective of STEP is to create a set of optics/ photonics textbooks for technicians. The first overview text, "Fundamentals of Photonics", is already under field test. Explore cord.org on the web for more details.

\section{INTRODUCTION:}

Optics is a very broad enabling technology whose demand is steadily increasing as communications, chemical, bio medical, biotech and other industries are rapidly growing. Consequently needs for optics/photonics technicians are steadily increasing around the world. The development of well-designed curriculum and texts are the first steps to promote technician education in community colleges. For this purpose the University of Connecticut and the "Center for Occupational Research and Development" (CORD), has 
developed the 3-level outline for eight potential Photonics books and completed the first book, "Fundamentals of Photonics" under an NSF grant, called STEP (Science and Technology Education in Photonics). Academic faculty and industry scientists created the outline of the curriculum based on skill sets defined by industry engineer, required for their laboratories and manufacturing plants. Ten faculty and industry scientists wrote the ten chapters of the first book. They all had previous authorship experiences. More detailed information about the curriculum outline and the book can be obtained from www.cord.org. This first book has been in circulation for industry comments and has been used in several community colleges and in one in-plant training site, JDS-Uniphase in Connecticut. The feedback varies from excellent to, "language and Mathematics are too tough for the community colleges". The detailed feedback clearly points to the necessity of utilizing the modern computer and internet/web technologies to meet the needs of diversity of requirements. Different industry sectors require emphasis on different optical science, engineering and technology. Required length and depth of educational training are different for different groups. The level of understanding is different for different student groups. And, at the same time technologies are changing these days quite rapidly, making technology examples in the lab obsolete within a couple of years.

It is under this background that we started thinking of issues related to how to develop and deliver books that are customizable to the needs of a variety of groups and updateable to accommodate rapid product obsolescence.

\section{PROPOSED APPROACH:}

First, we looked at contents of a selected set of books to understand whether there is any specific, scientific logic or pattern behind the organization of traditional books on optical sciences and technologies. View graphs or VG1 and VG2 present the summary for four books: (i) "Bible" of classical optics by Born and Wolf, (ii) undergraduate level book by Klein, (iii) Fundamentals of Photonics produced by our project STEP for technicians and edited by Guenther, Pedrotti and Roychoudhuri, (iv) an advanced senior level text by Saleh and Teich. The organizational flow in all these books can be characterized as a mixture of historical evolution of optical sciences, and applications of basic concepts and their applications to complex situations. It is difficult to conceive of approaches by which these books can be made customizable and updateable to exploit rapidly advancing and globally expanding computer and web technologies. A computer can identify and classify knowledge and information most efficiently when they are organized as identifiable "bits" (however complex that may be), with logical definitions created for the data cells. Then they can be organized and re-organized to meet the needs of customizability and update ability once these logical trees are defined and correlated with the core knowledge and technology information bits.

So we start at the very root with epistemology or methodology of creating scientific knowledge. VG3 summarizes the definitions. It helps us identify and distinguish invariant scientific principles from applied engineering principles and functional instruments 
invented by engineers. Then we come to a succinct but most generalized definition of optics/photonics (VG4) that lays the foundation for defining scientific and technological knowledge and information bits. An almost complete catalogue of basic and derived optical phenomena (knowledge) is given in VG5. We now need to figure out how to separate this optical knowledge into invariant (or at least very slowly varying) science and rapidly varying (changing) applied technologies manifested as instruments and devices. VG6 represents an attempt to present a comprehensive phenomenological (or physics) classification of all optical sciences. And, VG7 represents classification of functional (operational) optical components and devices, whose assemblage in, old or new versions or, macro or micro versions, give rise to all possible instruments and devices, including most of the future innovations. This is reasonably comprehensive, because the functional definition of optics is almost all encompassing. Thus we can create both an invariant optical science section and an invariant optical engineering (or technology) section. Then all the new innovations (instruments and devices) will be explained by combinations of knowledge bits from these two sections of science and engineering. However, for advanced students, there can be a better approach based on ecological or system thinking (VG8) where the functional elements are combined to create independent systems. This is based on the over-arching concept that all optical systems can be classified into those that (i) gather information, (ii) transport information, and (iii) deliver energy.

With such generic classification of optical science and engineering, we are now in a position as to how to start addressing customizability (VG9). One can now easily envision how to customize curriculum content to match the needs of different industry sectors. However, customizing to match the needs of students with different styles of learning and different intrinsic intelligences is quite complex. But, we will have to learn to address these complex and socially important requirements with parallel research projects. Substantial research effort must be devoted to these issues since global educational enterprise is still essentially under the control and concern "of the elite, by the elite and for the elite", because of the prevailing economic constraints. The problem is further complicated because most of the science educational materials are created and delivered by people who are essentially analytical, articulate and left-brain dominated. Their perception of intelligence does not proactively match those of the majority of the students. We still have a long way to go to appreciate that learning styles of people are different and their intrinsic intelligences may not be positively challenged or stimulated by pushing traditional analytical approach only.

Update ability (VG10), of course, will be much easier to deliver using our approach of separating slowly varying science and engineering knowledge "bits" (core competency) from the rapidly changing instruments and devices (technical currency). Once such a book has been designed to be web-smart, references for the latest instruments and devices can be made at the right place of the text with "hot-links" to a number of companies who manufacture such items. These companies can be requested to maintain "tutorial" web sections on their devices that complement (flows well with) the desired section of the book. It is to the best interest of the companies to update such "tutorial" web-segment as they introduce newer models or technologies. Thus, update ability of the rapidly changing 
technology segments of the knowledge "bits" can be obtained at a minimal cost to the educational community.

So, the basic approach to curriculum organization (VG11) is to assure close collaboration between academia and industry. The industry creates the "Task List" which is translated jointly by the industry and academia into task specific skill list that can be correlated to the science and technology knowledge bits. The academia then organizes the required material into a curriculum that also covers all the basic optical "Sciences Standard". We conclude with the overall logic flow of our concept that can be appreciated from the VG12 that underscores the collaborative functions of the academia and the industry.

ACKNOWLEDGEMENTS: Financial support for the project STEP comes from the National Science Foundation (grant \#DUE 9752029) of the United States of America. 


\section{PEDAGOGICAL ORGANIZATION OF \\ CURRENT TEXTS}

\section{Born \& Wolf}

1.Properties of E M

Fields

2.E M Potentials \&

Polarization.

3.Geom. Basic

4.Geom. Imaging

5.Geom. Aberration

6.Interference \&

Interferometry

7.Diffraction

8.Diffraction Theory, Aberration

9.Partial Coherence

10.Rigorous Diff.

Theory $\underline{\text { Klein }}$

1.Wave Propagation

2.Geometrical Optics

3.Paraxial Optics

4.Geo. Practical

(Radiometry/Photo-

metry/Aberration)

5.Interference

6.Coherence

7.Diffraction-Farfield

8.Diffraction- Fresnel

9.Diffraction-Image

formation

10.Polarization

11.E.M.Nature.
Guenther et al

1.Nature \& Properties of Light

2.Light Sources \& Laser Safety

3.Basic Geom. Optics

4.Basic Physical Optics

5.Lasers

6.Opt. Detectors \& Human

Vision

7.Optical Waveguides \& Fibers

8.Fiber Optics \&

Telecommunications

9.Photonic Devices for Imaging

\& Display

10.Basic Principals \&

Applications Of Holography

VG1

\section{$\underline{\text { Saleh \& Teich }}$}

1.Ray Optics

2.Wave Optics

3.Beam Optics

4.Fourier optics

5.E. M. Optics

6.Polarization \& Crystals

7.Guided Wave Optics

8.Fiber Optics

9.Resonator Optics

10.Statistical optics

11.Photon Optics

12.Photons and Atoms
13.Laser Amplifier

14.Lasers

15.Photons in Semiconductors

16.Semiconductor Photon Sources

17.Semiconductor Photon Detectors

18.Electro Optics

19.Non Linear Optics

20.Acousto Optics

21.Photonic Switching \& Computing

22.Fiber Optic Communication

VG2 


\section{EPISTEMOLOGY (METHODOLOGY OF THINKING)}

Science, engineering \& technology thinking:

Observe, catalogue \& classify natural phenomena.

In our case, light-matter interaction effects.

- Science - develop generalized models to explain largest possible number of observed phenomena \& possibly predict new ones.

- Engineering - understand natural phenomena. then learn to become an application specialist and innovator.

- Technologist- understand operations of current devices and instruments. then innovate $\&$ manufacture new ones.

VG 3

\section{WHAT IS OPTICS/PHOTONICS ?}

PHYSICISTS'

PHENOMENOLOGICAL APPROACH

Understanding light-matter interactions

ENGINEERS' \& TECHNOLOGISTS' FUNCTIONAL APPROACH

Generate, propagate, manipulate \& detect light by practical gadgets \& systems 


\section{CATALOGUE OF BASIC (\& DERIVED) OPTICAL PHENOMENA (LIGHT-MATTER INTERACTION)}

1.Reflection (Laws; Plane, Curved and Rough surfaces; Imaging properties; etc.)

2.Refraction (Snell's Law; Total internal refln., Lenses; Prisms; Imaging; etc.) 3.Polarization (Malus' Law; Brewster angle; Double refraction; etc.) 4.Interference (Superposition principle; Two-beam; Multiple beam, etc.) 5.Diffraction (H-F Principle; Near field; Far field; Grating; etc.) 6. Coherence \& Partial coherence (Interference \& Diffraction with complex sources)

7. Dispersion (Refractive; Diffractive; Interferometric Dispersion )

8.Electro-optic effects (Pockel; Kerr; Liquid Crystals; etc.)

9.Acousto-optics effects (Bragg \& Raman-Nath Diffractions; etc.)

10.Photoelectric effect (Photo-emissive coating, Semiconductor detectors: etc.)

11.Fourier optics (Image processing; Optical computing; etc.)

12.Holography (Construction \& Reconstruction Principles; etc.)

13.Laser Light Sources (Gas, solid, liquid \& semiconductor lasers; etc)

14.Thermal Light Sources (Filament \& Discharge lamps; Color LEDs; Flat panels; etc.)

15.Atomic \& Molecular Spectra (Fluorescence; Phosphorescence: etc.) 16.Nonlinear Optics (SHG; Raman, Brillouin \& Rayleigh Scattering; etc.)

\section{NATURE OF LIGHT}

1.Unification of Electromagnetic Phenomena (Maxwell's four equations; etc.)

2.Maxwell's Wave Equation (Velocity of light; Amplitude; Phase; Frequency; etc.)

3.Wave Propagation (Huygens-Fresnel Principle; Atoms \& Molecules as Dipoles; etc.)

VG 5 


\section{KNOWLEDGE CLASSIFICATION \\ FUNCTIONAL (TECHNOLOGICAL) THINKING}

\begin{tabular}{|c|c|c|c|}
\hline$\frac{\text { GENERATION }}{\text { (SOURCES) }}$ & $\mid \frac{\text { PROPAGATION }}{\text { WAVEFRONT CONTRL) }}$ & $\frac{\text { MANIPULATION }}{\text { (AMP.,PHAS.,FREQ.,POL.) }}$ & $\frac{\text { DETECTION }}{\text { (ENERGY SENSNG) }}$ \\
\hline \multicolumn{4}{|c|}{ BASIC DEVICE FUNCTIONS } \\
\hline $\begin{array}{l}\text { 1. THERMAL } \\
\text { SOURCES } \\
\text { 2 LASER SOURCES } \\
\text { 3. ETC. }\end{array}$ & $\begin{array}{l}\text { 1. LENSES } \\
\text { 2. PRISMS } \\
\text { 3. WAVEGUIDES } \\
\text { 4. POLARIZERS } \\
\text { 5. GRAD.INDX } \\
\text { DEVIES } \\
\text { 6. } \text { ETC. } \\
\end{array}$ & $\begin{array}{l}\text { 1. MODULATORS } \\
\text { 2. } \lambda \text { MUX/DEMUX } \\
\text { 3. } \lambda \text { TUNING } \\
\text { 4. ETC. }\end{array}$ & $\begin{array}{l}\text { 1. PHOTO TUBES } \\
\text { 2. PIN DETECTOR } \\
\text { 3. APD } \\
\text { 4. THERML DETECTOR } \\
\text { 5. PHOTO- } \\
\text { ACOUSTIC DET. } \\
\text { 6. ETC. } \\
\end{array}$ \\
\hline $\begin{array}{l}\text { COMPOUND DEVICE FU } \\
\text { 1. FLAT PANEL DIS. } \\
\text { 2. ADVANCED LASER } \\
\text { SYSTEMS: } \\
\lambda \text { TUNING; } \\
\text { NS, PS, FS - } \\
\text { PULSES; ETC. } \\
\text { 3. ETC. }\end{array}$ & $\begin{array}{l}\text { NCTIONS: } \\
\text { 1. TELESCOPES } \\
\text { 2. MICROSCOPES } \\
\text { 3. CAMERAS } \\
\text { 4. FIBER OPTICS } \\
\text { SYSTEMS } \\
\text { 5. NEAR FIELD } \\
\text { MICROSCOPES } \\
\text { 6. ETC. }\end{array}$ & $\begin{array}{l}\text { 1. SPECTROMETER } \\
\text { 2. OPTICAL SWITCH } \\
\text { 3. OPTICAL COMP. } \\
\text { 4. LASER LIGHT SHOW } \\
\text { 5. ETC. }\end{array}$ & $\begin{array}{l}\text { 1. DET. ARRAY } \\
\text { 2. STREAK CAM. } \\
\text { 3. INFRA. CAM. } \\
\text { 4. PHOTON CNT. } \\
\text { 5. MICROCHANN. } \\
\quad \text { PLATES } \\
\text { 6. ETC. } \\
\end{array}$ \\
\hline
\end{tabular}

\section{FUNCTIONAL (TECHNOLOGICAL) THINKING}

\begin{tabular}{|c|c|c|c|}
\hline$\frac{\text { GENERATION }}{\text { (SOURCES) }}$ & $\begin{array}{l}\text { PROPAGATION } \\
\text { (WAVEFRONT CONTRL) }\end{array}$ & (AMANIPULATION & (ENERGY SENSNG) \\
\hline \multicolumn{4}{|c|}{ BASIC DEVICE FUNCTIONS: } \\
\hline $\begin{array}{l}\text { 1. THERMAL } \\
\text { SOURCES } \\
\text { 2. LASER SOURCES } \\
\text { 3. ETC. }\end{array}$ & $\begin{array}{l}\text { 1. LENSES } \\
\text { 2. PRISMS } \\
\text { 3. WAVEGUIDES } \\
\text { 4. POLARIZERS } \\
\\
\text { 5. GRAD.INDX } \\
\text { DEVICES } \\
\text { 6. ETC. }\end{array}$ & $\begin{array}{l}\text { 1. MODULATORS } \\
\text { 2. } \lambda \text { MUX/DEMUX } \\
\text { 3. } \lambda \text { TUNING } \\
\text { 4. ETC. }\end{array}$ & $\begin{array}{l}\text { 1. PHOTO TUBES } \\
\text { 2. PIN DETECTOR } \\
\text { 3. APD } \\
\text { 4. THERML } \\
\text { DETECTOR } \\
\text { 5. PHOTO- } \\
\text { ACOUSTIC DET. } \\
\text { 6. ETC. }\end{array}$ \\
\hline \multicolumn{4}{|c|}{ COMPOUND DEVICE FUNCTIONS: } \\
\hline $\begin{array}{l}\text { 1. FLAT PANEL DIS. } \\
\text { 2. ADVANCED LASER } \\
\text { SYSTEMS: } \\
\lambda \text { TUNING; } \\
\text { NS, PS, FS- } \\
\text { PULSES; ETC. } \\
\text { 3. ETC. }\end{array}$ & $\begin{array}{l}\text { 1. TELESCOPES } \\
\text { 2. MICROSCOPES } \\
\text { 3. CAMERAS } \\
\text { 4. FIBER OPTICS } \\
\text { SYSTEMS } \\
\text { 5. NEAR FIELD } \\
\text { MICROSCOPES }\end{array}$ & $\begin{array}{l}\text { 1. SPECTROMETER } \\
\text { 2. OPTICAL SWITCH } \\
\text { 3. OPTICAL COMP. } \\
\text { 4. LASER LIGHT SHOW } \\
\text { 5. ETC. }\end{array}$ & $\begin{array}{l}\text { 1. DET. ARRAY } \\
\text { 2. STREAK CAM. } \\
\text { 3. INFRA. CAM. } \\
\text { 4. PHOTON CNT. } \\
\text { 5. MICROCHANN. } \\
\text { PLATES } \\
\text { 6. ETC. }\end{array}$ \\
\hline
\end{tabular}




\section{ECOLOGICAL OR SYSTEM THINKING LIGHT HELPS (i) GATHER INFORMATION, (ii) TRANSPORT INFORMATION AND (iii) DELIVER ENERGY.}

\begin{tabular}{|c|c|c|}
\hline GATHER INFORMATION & TRANSPORT INFORMATION & DELIVER ENERGY \\
\hline $\begin{array}{l}\text { 1. SPECTROSCOPIC } \\
\text { SENSING. } \\
\text { 2. OTHER OPICAL } \\
\text { SENSING (TEMP.,PRES.) } \\
\text { 3. LASER RADAR. } \\
\text { 4. IMAGING. } \\
\text { 5. SCATTERING } \\
\text { 6. COMBINATION OF } \\
\text { THE ABOVE. } \\
\text { 6. ETC. }\end{array}$ & $\begin{array}{l}\text { 1. FIBER OPTIC } \\
\text { COMMUNICATIONS. } \\
\text { 2. WIRELESS } \\
\text { COMMUNICATIONS. } \\
\text { 3. ETC. }\end{array}$ & $\begin{array}{l}\text { 1. LASER MACHINIG - } \\
\text { WELDING, CUTTING, } \\
\text { DRILLING, ETC. } \\
\text { 2. LASER MATERIAL } \\
\text { PROCESSING - } \\
\text { WRITING WAVEGUIDES }\end{array}$ \\
\hline
\end{tabular}

ISSUES: Response to rapid product obsolescence.

\section{UPDATABILITY}

APPROACH: Separate contents of book into -

Invariant ( slowly changing) science \& engineering given by foundational optical phenomena \& device functions. (CORE COMPETANCY)

Rapidly changing technologies underscored by current commercial components, devices, instruments \& systems. (TECHNICAL CURRENCY)

\section{CUSTOMIZABILITY}

ISSUES:

1. Different industry sectors need different skill set.

2. different learners have different learning styles, speeds \& level of competencies.

APPROACHES:

1. INDUSTRY

Elaborated earlier as industry-academia partnership in defining skill list and correlating with foundational knowledge components.

2. LEARNERS this topic needs extensive research. very difficult \& controversial issues involve socio-economic status, cultural emphasis to socio-economic issues, intrinsic \& socially acquired intelligences, knowledge required to build sustainable global economy while retaining cultural diversity, etc., etc.

VG 9 


\section{CURRICULUM ORGANIZATIONAL APPROACH}

\section{SYNTHESIS OF}

INDUSTRY TASK SPECIFIC LIST

ACADEMIC STANDARD BASED LIST

- Industry engineers provide industry specific task list.

- Educators \& engineers jointly identify the task list with the skills to be learnt from the knowledge components identified in the list of "functional thinking" \& "phenomenological thinking.

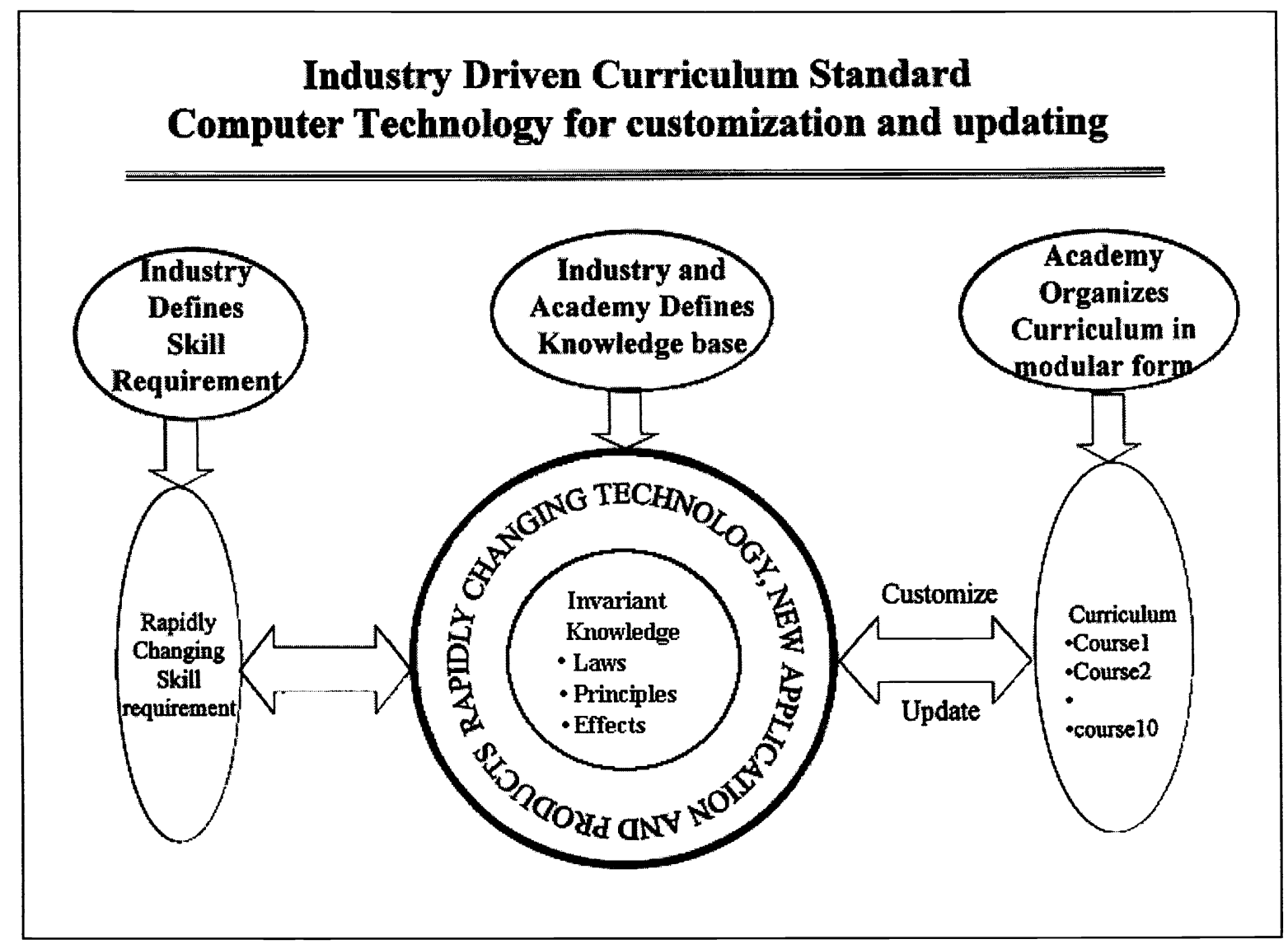

VG 12 